\title{
Comparing static linear and nonlinear analyses of safe rooms in a poor performance masonry building
}

\author{
M. Mazloom \\ Department of Civil Engineering, Shahid Rajaee University, Iran
}

\begin{abstract}
The idea of safe rooms has been developed for decreasing the earthquake casualties in masonry buildings. The information obtained from previous ground motions occuring in seismic zones expresses the lack of enough safety of these buildings against earthquakes. For this reason, an attempt has been made to create some safe areas inside the existing masonry buildings, which are called safe rooms. The practical method for making these safe areas is to install some prefabricated steel frames in some parts of the existing structure. These frames do not carry any service loads before an earthquake. However, if a devastating earthquake happens and the load bearing walls of the building are destroyed, some parts of the floors, which are in the safe areas, will fall on the roof of the installed frames and the occupants who have sheltered there will survive. This paper presents the performance of these frames located in a destroying three storey masonry building with favorable conclusions. In fact, the experimental pushover diagram of the safe room located at the ground-floor level of this building is compared with the analytical results and it is concluded that pushover analysis is a good method for seismic performance evaluation of safe rooms. Also this experimental diagram shows that the strength and displacement capacity of the steel frame are adequate to accommodate the distortions generated by seismic loads and aftershocks properly.

Keywords: earthquake, masonry building, casualties, safe room, vibration.
\end{abstract}

\section{Introduction}

Brick masonry has been used as a load bearing material for centuries. In gravity structures constructed by this material, the level of gravity stresses are low and 
the factor of safety against compression failure is high [1]. Moreover, there is no need for high technology to construct them; as a result, they are not expensive. These advantages of masonry buildings persuade some people to construct and utilize them. But masonry structural elements, which can only bear small tensile stresses, can not resist earthquake effects [2-7].

Any strengthening of an existing structure varies from case to case depending on the specific situation which needs to be considered [8]. Also, solutions to strengthening problems require a high degree of individual attention to detail and there is a wide range of expensive choices for design and construction method. In other words, strengthening of the existing structures is expensive and time consuming.

Safe room is the name of a new method, which is neither expensive nor time consuming, for lowering earthquake casualties in masonry buildings. In this method some safe rooms will be prepared inside the building and the existing load carrying system of the structure does not strengthen. To check this suggestion, the performance of some safe rooms located in a demolishing three storey masonry building is presented in this paper. Baker et al. have introduced a similar shelter for saving the human lives against bomb explosions [9]. This shelter, which is like a table, is capable of accommodating a family of two adults and two children in such a way that if the house collapses completely, due to a near miss from a large bomb, the occupants will not be crushed by the derbies and they will be able to escape or be rescued in a short time.

In an ideal world there would be no debate about the proper method of demand prediction and performance evaluation of the steel frames of safe rooms at low performance levels. Clearly, inelastic time history analysis that predicts with sufficient reliability the forces and cumulative deformation demands in every element of the structural system is the final solution. The implementation of this solution requires the availability of a set of ground motion records that account for the uncertainties and differences in severity, frequency characteristics, and duration due to rupture characteristics and distances of the various faults that may cause motions at the site. Moreover, it requires the adequate knowledge of element deformation capacities with due regard to deterioration characteristics that define the limit state of acceptable performance.

It should be worked towards this final solution, but it is also needed to recognize the limitations of today's states of knowledge and practice. Recognizing these limitations, the task is to perform an evaluative process that is relatively simple, but captures the essential features that significantly affect the performance goal. In this context, the accuracy of demand prediction is desirable, but it may not be essential, since neither seismic input nor capacities are known with accuracy. Using inelastic pushover analysis for the steel frames of safe rooms, which is the subject of this paper, serves this purpose provided its limitations and pitfalls are fully recognized.

\section{Static nonlinear analysis}

The purpose of static nonlinear or pushover analysis is to evaluate the expected performance of a structural system by estimating its strength and deformation 
demands in design earthquakes by means of a static inelastic analysis, and comparing these demands to available capacities at the performance levels of interest. The evaluation is based on an assessment of important performance parameters, including global drift, interstorey drift, inelastic element deformations, deformations between elements, and element and connection forces for elements and connections that cannot sustain inelastic deformations. The inelastic pushover analysis can be viewed as a method for predicting seismic force and deformation demands, which accounts in an approximate manner for the redistribution of internal forces occurring when the structure is subjected to inertia forces that no longer can be resisted within the elastic range of structural behaviour.

Pushover analysis is expected to provide information on many response characteristics that cannot be obtained from an elastic static or dynamic analysis. The followings are some examples of such response characteristics [10]: the realistic force demands in potentially brittle elements, such as axial force demands in columns, force demands in brace connections, moment demands in beam-to-column connections, shear force demands in deep reinforced concrete spandrel beams, shear force demands in unreinforced masonry wall piers; estimates of the deformation demands for elements that have to deform inelastically in order to dissipate the energy imparted to the structure by ground motions; consequences of the strength deterioration of individual elements on the behaviour of the structural system; identification of the critical regions in which the deformation demands are expected to be high and that they have to become the focus to thorough detailing; identification of the strength discontinuities in plan or elevation that will lead to changes in the dynamic characteristics in the inelastic range; estimates of the interstorey drifts that account for strength or stiffness discontinuities and p-delta effects; verification of the completeness and adequacy of load path, considering all the elements of the structural system, all the connections, the stiff nonstructural elements of significant strength, and the foundation system.

Static pushover analysis has no rigorous theoretical foundation. It is based on the assumption that the response of the structure can be related to the response of an equivalent single degree-of-freedom (SDOF) system. This implies that the response is controlled by a single mode, and that the shape of this mode remains constant throughout the time history response. Because each safe room contains a SDOF structural system, pushover analysis can be used for its seismic performance evaluation. It should be emphasized that both assumptions above are correct in this simple structure. However, those assumptions are incorrect in multi degree-of-freedom (MDOF) structures but pilot studies carried out by several investigators have indicated that these assumptions lead to rather good predictions of the maximum seismic response of MDOF structures, provided their response is dominated by a single mode [11-13].

\section{Experimental work}

The constructed three storey masonry building contained two $3 * 4 \mathrm{~m}^{2}$ rooms. The façade of the building can be seen in figure 1 . The steel frames were installed in 
the southern rooms of all the floors. It should be noted that all the installed frames were concentric.

Jack arch masonry slabs were utilized for constructing the entire three floors of the masonry building. There is a comprehensive research about the seismic behaviour of jack arch masonry slabs and their poor seismic performance has been highlighted there [3]. To overcome this shortcoming, some horizontal bracings were used for connecting the bottom flanges of the beams. These bracings improved the rigidity of the masonry slabs. After finishing the construction work, the rooms were decorated and some statues were located there.

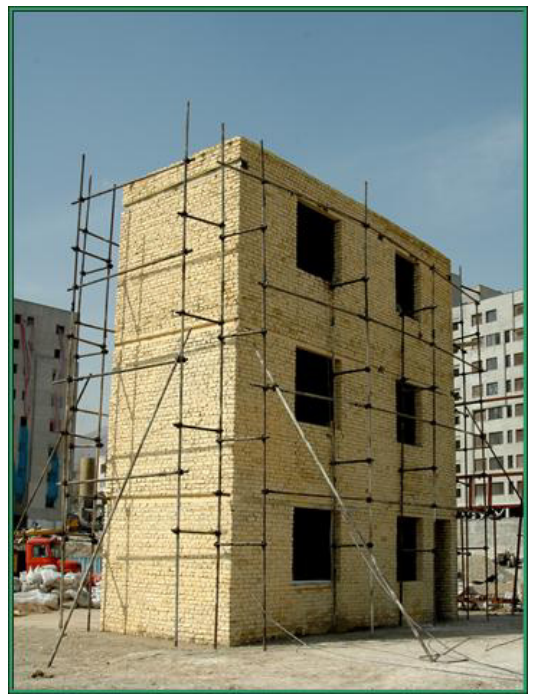

Figure 1: The three storey masonry building.

To impose the devastating horizontal forces to the building, some steel hooks were welded to its lintels. Then, some cables connected these hooks to three heavy vehicles. The angles between the moving directions of these three vehicles were about $120^{\circ}$. To create some vibrations in the demolishing building, the second and third vehicles started moving with a very small delay from the first and second one respectively.

Figure 2 shows the building at the time of destruction. It is clear that the lateral loads were very serious and devastating. According to figure 3, similar to the buildings located very near an active fault, all parts of the masonry building collapsed. However, it can be seen that the safe rooms carried the shock and impact loads generated by the collapsing masonry building properly and also the statues located inside the safe areas did not crush by the derbies.

To control the safe rooms against vibrations caused by aftershocks, a lateral drift of $20 \mathrm{~cm}$ was imposed to the frame of the first floor. This horizontal displacement was within the elastic limit of the structure. The amount of the 
applied force was $2200 \mathrm{kgf}$, which was about $10 \%$ of the total weight of the remaining system. Afterwards, the end part of the cable was cut; consequently, a free vibration happened in the remaining structure. This steel structure reacted properly and after finishing the free vibration, the structural system returned to its initial position with no destruction or overturning.

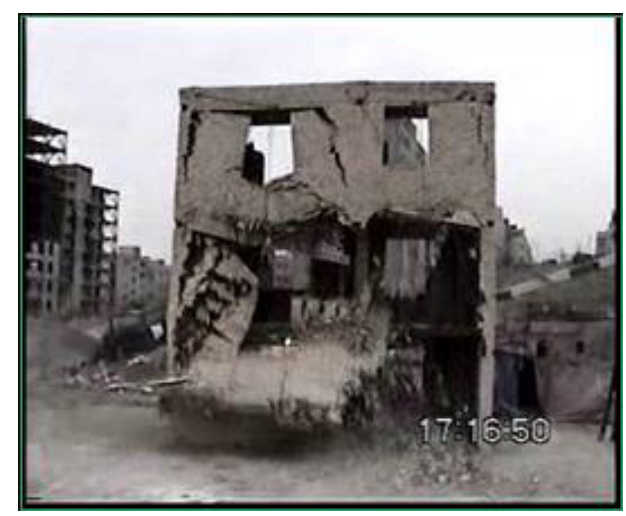

Figure 2: $\quad$ The demolishing masonry building.

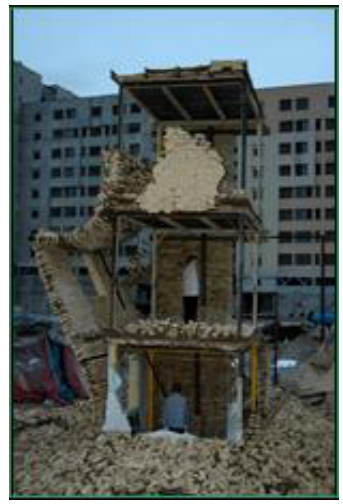

Figure 3: Operation of the safe rooms after collapsing the load bearing walls.

\section{Seismic performance evaluation}

In this part of the research, the lateral force-horizontal displacement relationship of the safe room located at ground-floor level was obtained to assess its seismic performance. For this purpose a pullback test was conducted and the incremental lateral displacements were imposed to the steel frame and the applied force in each step was measured. In figure 4, the total base shear in each step is plotted against the accompanied roof level lateral drift. In this figure, the results of static-linear and pushover analyses can be observed too. According to this figure 
the stiffness coefficients $(k)$ obtained from static linear analysis, pushover analysis and laboratory tests were $181 \mathrm{kgf} / \mathrm{cm}, 91.9 \mathrm{kgf} / \mathrm{cm}$ and $120 \mathrm{kgf} / \mathrm{cm}$ respectively. The natural period $T$ calculated according to the $k$ values above were $2.19 \mathrm{sec}, 3.07 \mathrm{sec}$ and $2.89 \mathrm{sec}$ respectively. Also the average $k$ value of static linear analysis and pushover analysis $\left(k_{a v r}\right)$ was $(181+91.9) / 2=136.45$ $\mathrm{kgf} / \mathrm{cm}$. The $T$ value obtained from $k_{\text {avr }}$ was $2.52 \mathrm{sec}$.

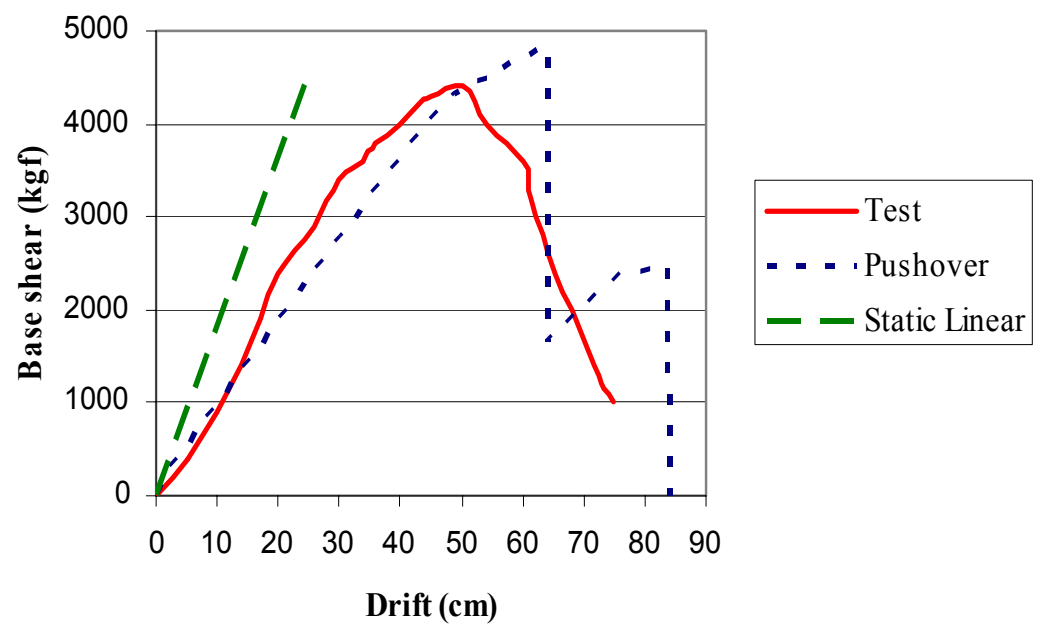

Figure 4: $\quad$ Pushover diagram of the investigated structure.

Standard No. 2800-05 [14] gives the following equation for measuring the lateral seismic load applied to the structure.

$$
F=[(A \cdot B \cdot I) / R] \cdot w
$$

where $A$ is design base acceleration, $B$ is response coefficient, $I$ is importance coefficient, $R$ is performance coefficient and $\mathrm{w}$ is vibrating weight of the building. In this standard $B$ is related to the natural period of vibration of the building, kind of the ground, and the seismic zones. Table 1 shows the calculated lateral loads of the steel frame located at ground-floor level in an area of high seismicity and the ground kind 2 . It can be seen that with reference to the experimental $T$ value the calculated lateral load $F$ is $1188 \mathrm{kgf}$. This load, which is not the lateral force resistance capacity of the frame, is the seismic load imposed to the structure according to standard No. 2800-05. It should be the best predicted lateral load because the experimental $T$ value, which is the real $T$ value, is utilized for calculating the response coefficient $B$. Of course, considering a slightly higher amount of applied load to the structure for its analysis and design creates a small margin of safety for the system against unprecedented happenings at the time of earthquake. It can be seen from Table 1 that pushover analysis underestimates and static linear analysis overestimates this value. The best prediction may be according to the $T$ value obtained from $k_{a v r}$, which shows the 
calculated lateral load $F$ is $1320 \mathrm{kgf}$. This value is about $11 \%$ higher than the one obtained from experimental $T$ value. In other words, an acceptable margin of safety will exist here if the $T$ value obtained from $k_{a v r}$ is utilized for estimating the imposed lateral seismic load $F$.

According to the experimental pushover graph of figure 4 the maximum force applied to the system was $4400 \mathrm{kgf}$, which was about $20 \%$ of the total weight of the remaining structure. This lateral force was more that two times of all the analytical seismic forces shown in Table 1 and also more than the calculated conservative value of $F=3850 \mathrm{kgf}$ according to standard No. 2800-05. These results pronounce the adequacy of strength capacity of the steel structure to accommodate the seismic loads.

Incorporation of all important structural response characteristics in the prediction of the SDOF displacement demand implies the ability to represent the load-deformation response of the structure with appropriate hysteretic characteristics. According to figure 4 the elastic SDOF displacement demand can be computed as $D_{e}=F / K$. The computed elastic displacement demands can be seen in Table 1. It is clear that the results of pushover analysis, experimental work, Standard No. 2800-05 and average analytical value were 12.1, 9.9, 21.3 and 9.7 centimeters respectively. These elastic displacement demands are the base lines for predicting the inelastic displacement demands, which need to be accomplished with due consideration given to the yield strength and hysteretic characteristics of the SDOF system. Both effects of yield strength and hysteretic characteristics can be accounted for through cumulative modification factors applied to the elastic displacement demands. It is worth noting that much information has been generated on the effect of yield strength on SDOF seismic demands [15-22]. In this research, the equation suggested by standard No. 280005 is utilized for calculating the inelastic displacement demands of the investigated safe room according to the elastic results. This equation is:

$$
D_{\text {ine }}=0.7 R . D_{e}
$$

where $R$ is performance coefficient, $D_{e}$ is elastic displacement demand and $D_{\text {ine }}$ is inelastic displacement demand. According to this equation, once the $R$-factor is known, the SDOF inelastic displacement demand can be computed. Standard No. 2800-05 suggests that the $R$-factor of ordinary moment resisting steel frames is equal to 5. Table 1 gives the inelastic displacement demands of the safe room according to the assumption above. It is clear that the maximum analytical amount of inelastic displacement demand is $42.4 \mathrm{~cm}$. The experimental pushover graph of figure 4 shows the drift at the time of ultimate lateral load and its maximum value were $50 \mathrm{~cm}$ and $75 \mathrm{~cm}$ respectively. In other words, all the analytical inelastic displacement demands were lower than the amount of roof displacement at the time of ultimate lateral force. Also standard 2800-05 gives the conservative amount of $74.6 \mathrm{~cm}$ for inelastic deformation demand, which is almost equal to the maximum experimental drift of $75 \mathrm{~cm}$. These results pronounce the adequacy of displacement capacity of the steel structure to accommodate the distortions generated by seismic loads and aftershocks properly. 
Table 1: $\quad$ Calculated seismic forces and displacement demands.

\begin{tabular}{|c|c|c|c|c|c|}
\hline \multirow{2}{*}{} & \multicolumn{5}{|c|}{ Different Methods } \\
\cline { 2 - 6 } & $\begin{array}{c}\text { Static } \\
\text { Linear } \\
\text { Analysis }\end{array}$ & $\begin{array}{c}\text { Pushover } \\
\text { Analysis }\end{array}$ & $\begin{array}{c}\text { Test } \\
\text { Result }\end{array}$ & $\begin{array}{c}\text { Standard } \\
\text { No. 2800- } \\
05\end{array}$ & $\begin{array}{c}\text { Average } \\
\text { Analytical } \\
\text { Value }\end{array}$ \\
\hline $\begin{array}{c}\text { Force F } \\
(\mathrm{kgf})\end{array}$ & 1430 & 1114 & 1188 & 3850 & 1320 \\
\hline $\begin{array}{c}\mathrm{D}_{\mathrm{e}}=\mathrm{F} / \mathrm{K} \\
(\mathrm{cm})\end{array}$ & 7.9 & 12.1 & 9.9 & 21.3 & 9.7 \\
\hline $\begin{array}{c}\mathrm{D}_{\text {ine }}=0.7 \mathrm{R} . \\
\mathrm{D}_{\mathrm{e}}\end{array}$ & 27.7 & 42.4 & 34.7 & 74.6 & 34 \\
\hline
\end{tabular}

\section{Conclusions}

The idea of a safe room is a practical solution for lowering the earthquake casualties in poor performance masonry buildings located at earthquake-prone areas. Because each safe room contains a SDOF structure, pushover analysis is a very good solution for evaluating its seismic performance. The experimental pushover diagram of the investigated structural system of the safe room located at the ground-floor level of a destructed 3 storey masonry building showed that the ductility, lateral stability and strength capacity of the structural system were quite satisfactory. Also the structures of the experimented safe rooms carried a considerable free vibration properly. Therefore, the structural system of the investigated safe rooms was capable of accommodating the distortions generated by seismic loads and aftershocks properly.

\section{References}

[1] Bakhteri, J. and Sambasivam, "Mechanical behaviour of structural brick masonry: an experimental evaluation," Proceedings of the $5^{\text {th }}$ Asia-Pacific Structural Engineering and Construction Conference, Johor Bahru, Malasia, August, 2003, 305-317.

[2] Rangelova, F. "Earthquake and blast shock loading on masonry veneer structures", $5^{\text {th }}$ Asia-Pacific Conference on Shock \& impact loads on Structures, Changsha, Hunan, China, November, 2003, 323-327.

[3] Maheri, M.R. and Rahmani, H. "Static and seismic design of one-way and two-way jack arch masonry slabs", Engineering Structures, 2003, 25, 1639-1654.

[4] Henderson, R.C., Fricke, K.E., Jones, W.D. and Beavers, J.E. "Summary of a large- and small-scale unreinforced masonry infill test program", Journal of Structural Engineering, December, 2003, 1667-1675. 
[5] Memari, A.M., Burnett, E.F.P. and Kozy, B.M. "Seismic response of a new type of masonry tie used in brick veneer walls", Construction and Building Materials, 16, 2002, 397-407.

[6] Taghdi, M., Bruneau, M. and Saatcioglu, M. "Analysis and design of lowrise masonry and concrete walls retrofitted using steel strips", Journal of Structural Engineering, September, 2000, 1026-1032.

[7] Barbieri, A., Mantegazza, G. and Gatti, A. "Behaviour of masonry walls subject to shear stresses and reinforced with FRCM", $2^{\text {nd }}$ Specialty Conference on the Conceptual Approach to Structural Design, Milan, Italy, July, 2003, 257-264.

[8] Ivanyi, G. and Buschmeyer, W. "Conceptual design in strengthening of concrete bridges", $2^{\text {nd }}$ Specialty Conference on the Conceptual Approach to Structural Design, Milan, Italy, July, 2003, 521-527.

[9] Baker, J.F., Horne, M.R. and Heyman, J., The Steel Skeleton, Volume II, Plastic Behaviour and design, The Cambridge University Press, 1956.

[10] Krawinkler, H., and Seneviratna, G. D. P. K. "Pros and cons of a pushover analysis for seismic performance evaluation", Engineering Structures, 20 (4-6), 1998, 452-464.

[11] Lawson, R. S., Vance, V. and Krawinkler, H. "Nonlinear static pushover analysis - why, when and how?", $5^{\text {th }}$ US Conference of Earthquake Engineering, Vol. 1, Chicago, IL, 1994, 283-292.

[12] Miranda, E. "Seismic evaluation and upgrading of existing buildings", Ph.D. dissertation, Department of Civil Engineering, University of California, Berkley, CA, 1991.

[13] Fajfar, P. and Fischinger, M. "N2 - a method for non-linear seismic analysis of regular structures", $9^{\text {th }}$ World Conference of Earthquake Engineering, Vol. 5, Tokyo-Kyoto, Japan, 1988, 111-116.

[14] Standard No. 2800-05, Iranian Code of Practice for Seismic Resistant Design of Buildings, $3^{\text {rd }}$ Edition, Building and Housing Research Center, PN S 253, 2005.

[15] Fajfar, P. and Krawinkler, H., Nonlinear seismic analysis and design of reinforced concrete buildings, Elsevier, London, 1992.

[16] Krawinkler, H. and Rahnama, M. "Effects of soft soils on design spectra", $10^{\text {th }}$ World Conference on Earthquake Engineering, Vol. 10, Madrid, Spain, 1992, 5841-5846.

[17] Miranda, E. and Bertero, V.V. "Evaluation of strength reduction factors for earthquake-resistant design", Earthquake Spectra, EERI, 1994, 10 (2), 357-379.

[18] Nassar, A.A. and Krawinkler, H. "Seismic demands for SDOF and MDOF systems", John A. Blume Earthquake Engineering Center, Report No. 95, Department of Civil Engineering, Stanford University, 1991.

[19] Nassar, A.A., Krawinkler, H. and Osteraas, J.D. "Seismic design based on strength and ductility demands", $10^{\text {th }}$ World Conference on Earthquake Engineering, Vol. 10, Madrid, Spain, 1992, 5861-5866.

[20] Newmark, N.M. and Hall, W.J. "Earthquake spectra and design", EERI Monograph Series, 1982. 
268 Earthquake Resistant Engineering Structures VI

[21] Rahnama, M. and Krawinkler, H. "Effects of soft soils and hysteresis models on seismic design spectra", John A. Blume Earthquake Engineering Center, Report No. 107, Department of Civil Engineering, Stanford University, 1993.

[22] Vidic, T., Fajfar, P. and Fischinger, M. "Consistent inelastic design spectra: strength and displacement", Earthquake Engineering and Structural Dynamics, 1994, 23. 